\title{
Development of an Integrated Metrô-Bus Transportation System Using the Mathematica Software
}

\author{
Rafael Cabidolusso Lavalle Heilbron'; Corbiniano Silva²; Paulo Fernando Lavalle Heilbron Filho3; \\ Gleide Borges Moraes Lacerda² \\ rafaelheilbron@hotmail.com
}

1. Catholic University of Rio de Janeiro, Gávea - RJ. 2. Federal University of Rio de Janeiro, Ilha do Fundão - RJ.

3. Brazilian Nuclear Energy Commission, Botafogo - RJ.

Histórico do Artigo:

Recebido em: 12 de maio de 2019 Aceito em: 18 de novembro de $2019 \quad$ Publicado em: 28 de dezembro de 2019

Abstract: The article shows the application of a program developed in the computational platform Mathematica, used to organize the urban transport that involves a conjugated metro-bus lines system for collective use. Three different bus lines were considered, connecting several neighborhoods. The results show the number of buses required, estimated times, arrival and departure times for three bus lines, from a hypothetical location, based on simulated data, showing the potential of numerical modeling to develop an integrated system with the subway. The program can be easily extended, allowing the inclusion of more bus lines and immediate results for any desired change / insertion of data, allowing a better and faster evaluation of the problem. The study and its results present an important tool of support and decision making to subsidize the urban transport planning of medium and large cities.

Keywords: Urban Transport, Integrated metro-bus system, Computational modeling, Mathematica.

\section{Desenvolvimento de um Sistema de Transporte Integrado Metrô-0̂nibus Utilizando o Software Mathematica}

Resumo: 0 artigo mostra a aplicação de um programa desenvolvido na plataforma computacional Mathematica, utilizada para organizar o transporte urbano que envolve um sistema de metro-linhas de ônibus conjugadas para uso coletivo. Três diferentes linhas de ônibus foram consideradas, conectando diversos bairros. Os resultados mostram o número de ônibus necessários, tempos estimados, horas de chegada e saída para três linhas de ônibus, a partir de uma localização hipotética, com base em dados simulados, mostrando o potencial da modelagem numérica para desenvolver um sistema integrado com o metrô. 0 programa pode ser facilmente estendido, admitindo a inclusão de mais linhas de ônibus e resultados imediatos para qualquer alteração/inserção de dados desejada, permitindo uma avaliação melhor e rápida do problema. 0 estudo e seus resultados apresentam uma ferramenta importante de suporte e tomada de decisão para subsidiar o planejamento do transporte urbano de médias e grandes cidade.

Palavras-chave: Transporte urbano, Sistema integrado ônibus-metrô, Modelagem computacional, Mathematica.

\section{Desarrollo de um Sistema de Transporte Integrado Metró-Autobús Utilizando el Software Mathematica}

Resumen: El artículo muestra la aplicación de un programa desarrollado en la plataforma computacional Mathematica, utilizada para organizar el transporte urbano que envuelve un sistema de líneas de autobús conjugadas para uso colectivo. Tres diferentes líneas de autobuses fueron consideradas, conectando diversos barrios. Los resultados muestran el número de autobuses necesarios, tiempos estimados, horas de llegada y salida para tres líneas de autobús, desde una ubicación hipotética, con base en datos simulados, mostrando el potencial del modelado numérico para desarrollar un sistema integrado con el metro. El programa puede ser fácilmente extendido, admitiendo la inclusión de más líneas de autobús y resultados inmediatos para cualquier cambio / inserción de datos deseada, permitiendo una evaluación mejor y rápida del problema. El estudio y sus resultados presentan una herramienta importante de soporte y toma de decisión para subsidiar la planificación del transporte urbano de medianas y grandes ciudades.

Palabras clave: Transporte urbano; Sistema integrado autobús-metro; Modelado computacional; Mathematica. 
Development of an Integrated Metrô-Bus Transportation System Using the Mathematica Software

\section{INTRODUCTION}

The circulation and movement of the population to work, schools, health, leisure, among other purposes, is a necessity of the human being, where collective transportation plays a fundamental role. However, with population growth there is an increase in the demand for transportation, triggering the expansion of the fleet of vehicles, reflecting the intensification of agglomerations and congestion in urban areas complicating the logistics of the road system becoming more complex.

As just pointed out by Carvalho (2016) forty years ago, the Brazilian population lived mostly in rural areas, without much demand for mass transportation in the few existing urban agglomerations. Today, about 85\% of the population lives in urban centers, and there are 36 cities with more than 500,000 inhabitants in the Brazilian urban network, as well as 40 established metropolitan regions, where more than 80 million Brazilians live (about $45 \%$ of the population).

According to IPEA (2011) it is worth mentioning the challenges faced by the rulers in the implementation of popular housing policies in regions far from the city important centers, that causes the immobility of the poorest and the formation of dormitory cities, putting increasing pressure on the global cost of transportation. Between the 2000 and 2010 censuses, the peripheral municipalities of the main Brazilian metropolitan regions had a much higher population growth than the central municipalities.

In medium and large cities, with increasing distances and times of travel on journeys, especially between peripheral areas and central regions, the level of bus parking, waiting time by the passengers and the logistics of the city show the low-level service provided to the population.

According to Pena (2017) the main cause of urban mobility problems in Brazil is related to the increased use of individual transport over the use of public transport, although the latter also encounter difficulties with overcrowding. This increased use of vehicles such as cars and motorcycles is due to:

a) The poor quality of public transportation in Brazil;

b) The increase in the average income of Brazilians in recent years;

c) The reduction of taxes by the Federal Government on industrialized products (which includes cars); 
d) The granting of more consumer credit;

e) The historical heritage of the country's road policy.

Also according to Pena (2017) between 2002 and 2012, according to data from the Observatory of the Metropolis, while the Brazilian population increased by $12.2 \%$, the number of vehicles registered a growth of $138.6 \%$. There are cities in the country that present a less than two inhabitants for each car present, which makes almost all measures impossible to guarantee a more efficient transport system.

This problem highlights the need for improvements in urban transport systems, whose progress in quality results from the integration of their systems, where indicators of accessibility, frequency of service, travel time, stocking, reliability, (Ferraz \& Torres, 2001). In addition, the use of public transport is a key factor in the quality of public transportation.

In this perspective, the adoption of integrated bus corridors to other transport systems (train, subway, light rail transport) and its better management in the logistics of cities contributes to the improvement of the quality of public transport.

One of the most important tasks relating to urban transport is the development and correct planning of a complete integrated system connecting, for example, metro and buses routes (Vuchic, 2005; 2007).

Usually, big cities have an integrated metro-bus complex system that has to be developed based on many studies and researches especially in the peak time traffic in order to have an optimized system. Almasi et al. (2016) based their integrated model based on geometric series but with focus on studies of the time, that a bus would stayed at the stop to load/unload other passengers in order to optimize the metro-bus system. Oguchi et al. (2017) on the other hand studied the inefficiencies that could result from a poor feeder service that, eventually, can make an urban mass transit system unsustainable. Thilakaratne et al. (2016) and Geurs et al. (2016) focused their modeling on the demand/supply interactions due to implementation of new technologies or changes in mode of service, especially, in regions where more than one transport feeder mode exists. The first author based his studies on a bus and van integrated metro system. The second analyzed the possibility of a bicycle - metro integration system.

Others authors based their work on modeling the effects of a station disruption, an abnormal operational situation when the entrance or exit gates of a metro station have to be closed for a certain of time due to an unexpected incident, establishing a model to solve the metro station disruption problem by providing optimal additional bus-bridging services in that 
Development of an Integrated Metrô-Bus Transportation System Using the Mathematica Software

case. There are many studies around the world involving integrated transport systems in order to improve their quality such those from:

- Chakrabarti \& Giuliano (2015) that used data from the Los Angeles metro-bus system to analyze the variation in intersections between the lines and to find the reliability of the service, being decisive to promote the sponsorship of transit systems with fixed schedules and routes, whose improvements in reliability can lead to productivity gains for traffic agencies;

- Chakrabarti (2015) that evaluated whether the reliability of the transportation service determines the number of transit passengers in the Los Angeles metro system, and whether its improvements helped to promote the number of transit passengers during the peak period of the system;

- Chen \& Tseng (2016) that examined the metro-bus intermodal system and its use by passengers, influenced by different amounts of information, which evaluated the managerial implications for metro-bus system agencies and applications in intermodal transfer services to other industries carriage;

- Cereja et al. (2012) that assessed the need for good intermodal connections in transport systems in Bangkok, Thailand, with actions that can improve the connections between metro and buses, suggesting improvements in intermodal bus-metro transfers, including security conditions against crime and the distance between metro exits and bus stops;

- Xin et al. (2016) that evaluated the multiperiod time optimization for metro networks, analyzing the problem of the optimization of train schedules for metropolitan transit networks to improve the performance of the synchronization of transfer between different railway lines, especially in the problem of optimization of schedules in the transition period (from peak to off peak hours or vice versa), where train advance changes and passenger travel demand vary significantly;

- Hidalgo (2009) that analyzed the interconnected transit system of São Paulo (Brazil), which optimized bus routes and services through the use of advanced technologies for tariff integration, fleet renewal and requirements for the provision of transit services and support infrastructure for buses (priority and exclusive tracks, bus stops, integration terminals and information systems and user control). The time integration scheme has changed the way passengers select a combination of services and has resulted in time and travel savings. A decrease in cars was identified, associated with the main complaints about high levels of pollution, congestion and long waiting periods and trips; 
- Jin et al. (2014) that evaluated Singapore's transport system via metro-bus integration, whose results show that the resilience of the metropolitan network to disruptions can be significantly improved from localized integration with public bus services;

- Kepaptsoglou \& Karlaftis (2009) that analyzed the metro network and its unexpected operational disruptions, with the rapid and efficient replacement of services needed to accommodate passengers, including the widely used "bridge" practice of metro stations using bus services, being proposed a methodological structure to plan and design an efficient network of bus bridges, bus route project and decision support system;

- Königsberg (2008) that presented an algorithm applied to the metro-bus public transport system in Mexico City to calculate a generalized model of regular reducible matrices over max-plus algebra, whose application allowed to obtain a schedule for the integrated transport system;

- Kumar et al. (2011) that assessed the metro-bus multimodal transport system in Nova Dheli (India), analyzing the integration and exchange of the system and the perceptions of safety of the exchange of passengers for the implementation of general and specific safety measures, elements that should contribute to make public transport systems safer;

- Li et al. (2011) that presented a statistical approach to predict the arrival time of public bus transportation, based on the traffic information management system, where several factors affect the travel time of buses (departure time, business day, location of buses, number of connections, number of intersections, passenger demand at each stop, and urban network traffic status to describe bus arrival times) were considered;

- Mata et al. (2011) that developed a mobile assistant application to locally locate and orient passengers of a bus-metro system in Mexico City, which assists blind or visually impaired passengers from an affordable and low-cost combination of mobile devices, GPS and compass to provide audible orientated functionalities and interfaces that indicate to a given user their location within the bus-metro system, with appropriate guidance instructions leading to boarding gates at that station, thanks to a developed guidance algorithm;

- Pekel \& Kara (2016) that established in Istanbul (Turkey) a fleet schedule, based on simulation in the metro-bus system to meet passenger satisfaction, whose shipment and landings distributions are determined in relation to the stochastic process and a model of discreet event built to determine at which point a bus embarks and disembarks from the metrobus. The results prove that the simulation-based fleet scheduling can be successfully applied to the metro system; 

Software

- Seriani \& Fernández (2015) that proposed directives to the planning of interchanges of the metro-bus system, through the application of a model of pedestrian microsimulation in Santiago of Chile;

- Song et al. (2012) that developed and applied a 'scientific approach' to improve the integration of metro-bus networks in Beijing, China, whose proposed approach can provide meaningful information for service planning in multimodal corridors in Chinese cities, where metropolitan networks are rapidly expanding;

- Yannis et al. (2012) that focus their work on the selection of indicators on the characteristics of the metropolitan network (length and number of stations, characteristics of the city: population and density), examined the extent of metropolitan rail network versus the needs of the city, in order to assist in estimating the adequacy of a metro network. The methodology was applied to estimate the degree of adequacy of the Athens metropolitan network (Greece) in relation to the needs of the city, whose results indicated that the metropolitan Athens network could not be characterized as adequate, with future proposals being network extensions, actions which served as an initial reference point in the planning process for the future development of the Athens metropolitan system, which outlined a future metro line network of eight lines, $220 \mathrm{~km}$ and 200 stations, setting long-term goals for the city's transport infrastructure;

- Yin et al. (2018) that developed a discrete three-tier choice behavior model to analyze the dynamic demand for passenger flow under metro station disruption; and an integrated algorithm designed to manage and control the station's outage crisis by providing additional bus bridging services in order to minimize the total travel time of affected passengers and the cost of bus bridges. In addition, multimodal transport modes, including metro, bus bridge, shared bike and taxi are considered alternative options of passengers in the face of the disruption of the station. A numerical study based on the Beijing Metro network shows that additional bus bridge services can significantly eliminate the negative impact of station disruption;

- Xiong et al. (2013) that developed a community bus routing project for metro stations, with optimization variables that include route and progress, presenting a solution to the ideal routing project problem, with the goal of minimizing the total cost, including costs of users and suppliers, considering the demand of passenger traffic and the budgetary restrictions. 
This article shows two examples of a metro-bus system developed using the Mathematica software language (Wolfram, 1996) considering a metro conjugated system with three different bus lines connected. All the data uses are hypothetical and the model can be improved to apply to a more complex transport scheme including others metro connecting options if desired (water boat transport, bicycle, etc), walking distance from metro and bus station, extra bus lines in case of accidents occurring in one of the stations, etc.

\section{METHODOLOGY}

The program for obtaining an integrated metro-bus system was developed based on the symbolic manipulation software known as Wolfram Matemathica originally developed by Stephen Wolfram. The software is continuously updated by a company called Wolfram Research that implements improvements in its computational algebra system and contains several programming libraries ready to be used for various purposes in the area of exact sciences, as is the case of engineering. Mathematica consists of two parts, which are an interface (also known as the "front end" and the kernel.) The kernel is the part that interprets the expressions and code of Mathematica and returns the results, while the graphical interface is where users work with more aesthetic graphic options and possible editions.

In order to develop an integrated metro bus system in one of the metro stops many information are necessary during the peak use such as (Correia, 2012):

- The number of passengers that uses the metro and that get off the metro on a determined platform;

- Bus distance routes to the end terminals;

- Average velocities of each bus on each of the possible routes;

- Percentages of passengers that uses the integrated bus three lines system (in this example) coming from the metro;

- Cadence of the metro service (interval time of each metro arrival at the station);

- Minimum time of permanence of each bus in the metro bus terminal;

- Minimum remain time for buses to stay in each suburban endpoints;

- Average velocity of each bus taking into consideration the stopping times during routes;

- Passengers capacity of each bus including number of seats and standing people. 
Development of an Integrated Metrô-Bus Transportation System Using the Mathematica Software

Based on those data it is possible to estimate the number of buses during the peak period, the timetable for each route and the number of buses that will park at the same time at the metro station stop in order to plan enough space for them.

Figure 1 below shows a typical integrated metro system (MS) in a city connecting three different bus lines to three end terminals (TA, TB and TC).

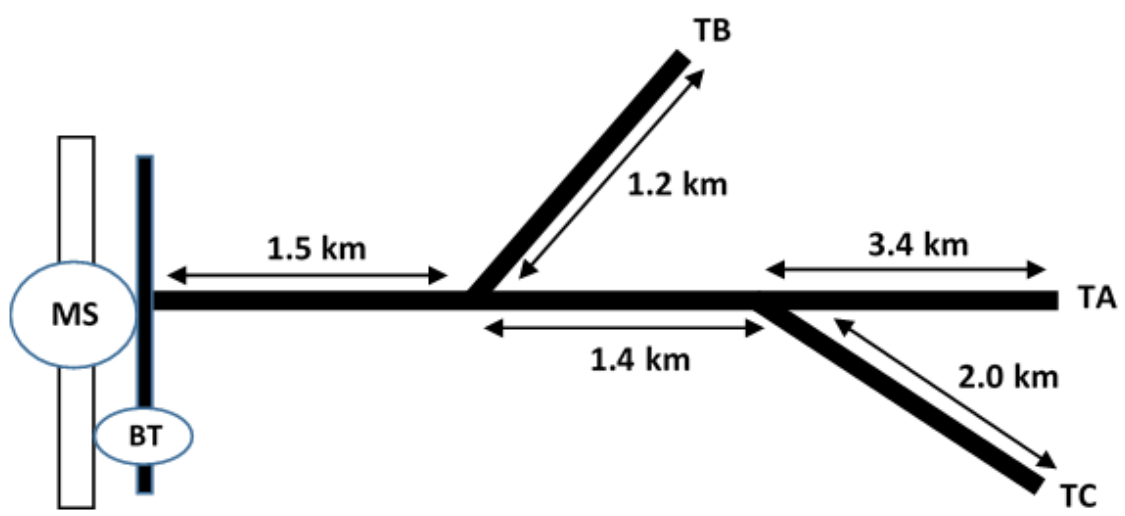

Figure 1. Transport System (not to scale).

Source: Authors example.

The total bus distance traveled DA, DB and DC for each route is equal to the sum of all the distances shown on Figure 1 for each of the bus lines.

The number of metro wagons MW per hour arriving at station is giving by equation 1 below:

$$
M W=60 / T s \quad(\text { Equation } 1)
$$

Where: Ts is the minimum time of permanence of each bus in the metro bus terminal.

The number of passengers per hour at the station NPS is calculated multiplying the number of passengers $\mathrm{N}$ that uses the metro and that get off the metro on the platform on peak time by the number of metro wagons per hour MW arriving at station as follows:

$$
N P S=N * M W \quad \text { (Equation 2) }
$$

The number of passengers that uses each line is calculated $\left(B_{A}, B_{B}\right.$ and $\left.B_{C}\right)$ based on the equation below:

$$
B_{n}=N P S * P m b * P_{n} \quad \text { (Equation 3) }
$$


Where:

- Index $\mathrm{n}$ is equal to $\mathrm{A}$ for route $\mathrm{A}, \mathrm{B}$ for route $\mathrm{B}$ and $\mathrm{C}$ for route $\mathrm{C}$;

- $\quad$ Pmb is the percentage of passengers that uses the integrated bus three lines system (in this example) coming from the metro and $P_{n}$ the respective percentage of passengers that comes from metro and uses lines n (A, B and C) respectively.

The number of circulating bus per hour for each line CBn can be calculated as follows:

$$
C B_{n}=B_{n} / B C \quad(\text { Equation } 4)
$$

Where:

- $\quad \mathrm{BC}$ is the capacity of each bus including passengers seated and standing;

- Index $\mathrm{n}$ is equal to $\mathrm{A}$ for route $\mathrm{A}, \mathrm{B}$ for route $\mathrm{B}$ and $\mathrm{C}$ for route $\mathrm{C}$.

On the other hand, the interval between bus departures $\mathrm{IBD}_{\mathrm{n}}$ for each line $\mathrm{n}$, in minutes, is calculated as follows:

$$
I B D_{n}=60 / C B_{n} \quad \text { (Equation 5) }
$$

Where:

- $\quad \mathrm{CB}_{\mathrm{n}}$ is calculated based on equation 4 :

The time spent from each bus line $\mathrm{n}, \mathrm{TB}_{\mathrm{n}}$, in minutes, considering comings and goings can be calculated as follows:

$$
T B_{n}=2 *\left(B_{n} * / V_{n}\right)+t s+t f \quad \text { (Equation 6) }
$$

- $\mathrm{D}_{\mathrm{n}}$ giving in $\mathrm{km}$;

- $\mathrm{V}_{\mathrm{n}}$ giving in $\mathrm{km} / \mathrm{min}$.

Finally, the number of necessary buses $\mathrm{NNB}_{\mathrm{n}}$ for each line $\mathrm{n}$ can be calculated as follows using equations 5 and 6 : 
Development of an Integrated Metrô-Bus Transportation System Using the Mathematica Software

$$
\left.N N B_{n}=T B_{n} / I B D_{n} \quad \text { (Equation } 7\right)
$$

Two examples of integrated metro system will be shown on the next item together with the set of data used on both cases.

\section{RESULTADOS E DISCUSSÃ0}

\section{Transport System Data}

Table 1 shows the obtained hypothetical necessary data for the calculation of the integrated system for the first case.

Table 1. System set of data for the first case.

\begin{tabular}{lc}
\hline \multicolumn{1}{c}{ System characteristic } & Values \\
\hline The number of passengers that uses the metro and that get off the & $\mathrm{N}=1200$ passengers \\
metro on the platform on peak time & $\mathrm{Pmb}=63 \%$ \\
Percentages of passengers that uses the integrated bus three lines & $\mathrm{PA}=27 \%$ \\
system (in this example) coming from the metro & $\mathrm{PB}=53 \%$ \\
Percentage of passengers that uses bus line TA & $\mathrm{PC}=20 \%$ \\
Percentage of passengers that uses bus line TA & $\mathrm{Cs}=12$ minutes \\
Percentage of passengers that uses bus line TA & $\mathrm{Ts}=5$ minutes \\
Cadence of the metro service (interval time of each metro arrival at & $\mathrm{Tf}=2$ minutes \\
the station) & \\
Minimum time of permanence of each bus in the metro bus terminal & \\
Minimum remain time for buses to stay in each suburban endpoints & \\
TA, TB and TC & $\mathrm{V}_{\mathrm{A}}=\mathrm{V}_{\mathrm{B}}=\mathrm{V}_{\mathrm{C}}=25 \mathrm{~km} / \mathrm{h}$ for all three \\
Average velocity of each bus including stopping times during route TA, & $\mathrm{BC}=100$ \\
TB and TC; & \\
Capacity of each bus including passengers seated and standing &
\end{tabular}

Table 2 shows the obtained hypothetical necessary data for the calculation of the integrated system for the second data case changing only the numbers of passengers that uses the metro on peak time and increasing the average velocities of the buses for the three lines.

Table 2. System set of data for the second case.

\begin{tabular}{lc}
\hline \multicolumn{1}{c}{ System characteristic } & Values \\
\hline The number of passengers that uses the metro and that get off the metro on & $\mathrm{N}=\mathbf{1 0 0 0}$ \\
the platform MS on peak time & Pmb=63\% \\
Percentages of passengers that uses the integrated bus three lines system (in & $\mathrm{PA}=27 \%$ \\
this example) coming from the metro &
\end{tabular}


Percentage of passengers that uses bus line B

Percentage of passengers that uses bus line $\mathrm{C}$

$\mathrm{PC}=20 \%$

Cadence of the metro service (interval time of each metro arrival at the

$\mathrm{Cs}=12$ minutes

station)

Minimum time of permanence of each bus in the metro bus terminal

Minimum remain time for buses to stay in each suburban endpoints TA, TB

$\mathrm{Ts}=5$ minutes and $\mathrm{TC}$

Average velocity of each bus including stopping times during route TA, TB and TC;

Capacity of each bus including passengers seated and standing

$\mathrm{Tf}=2$ minutes Source: Authors.

$\mathrm{V}_{\mathrm{A}}=\mathrm{V}_{\mathrm{B}}=\mathrm{V}_{\mathrm{C}}=30 \mathrm{~km} / \mathrm{h}$ for all

three $\mathrm{BC}=100$

All the equations were introduced in a program developed on the "Mathematica "symbolic platform" and table 3 below shows the results for the first proposed case using the data set of table 1.

Table 3. System results for the first set of data from table 1 .

\begin{tabular}{|c|c|}
\hline System characteristic & Values \\
\hline Total distance MS-TA & $\mathrm{DA}=6.3 \mathrm{~km}$ \\
\hline Total distance MS-TB & $\mathrm{DB}=4.1 \mathrm{~km}$ \\
\hline Total distance MS-TC & $\mathrm{DC}=3.5 \mathrm{~km}$ \\
\hline Average velocity on all routes & $V_{A}=V_{B}=V_{C}=0.416667 \mathrm{~km} / \mathrm{min}$ \\
\hline $\begin{array}{l}\text { Number of metro wagons per hour arriving at } \\
\text { station }\end{array}$ & \\
\hline Number of passengers per hour at the station & 6000 passengers $/ \mathrm{h}$ \\
\hline Number of passengers that takes bus line $B_{A}$ & 1021 passengers/hour \\
\hline Number of passengers that takes bus line $B_{B}$ & 2004 passengers/hour \\
\hline Number of passengers that takes bus line $B_{C}$ & 756 passengers/hour \\
\hline Number of circulating bus per hour for line $\mathrm{CB}_{\mathrm{A}}$ & $\begin{array}{r}\text { ROUNDED = } 11 \text { circulation buses/hour (not the } \\
\text { number necessary per line) }\end{array}$ \\
\hline Number of circulating bus per hour for line $\mathrm{CB}_{B}$ & $\begin{array}{r}\text { ROUNDED }=21 \text { circulation buses/hour (not the } \\
\text { number necessary per line) }\end{array}$ \\
\hline Number of circulating bus per hour for line $\mathrm{CB}_{\mathrm{C}}$ & $\begin{array}{r}\text { ROUNDED }=8 \text { circulation buses/hour (not the number } \\
\text { necessary per line) }\end{array}$ \\
\hline Interval between bus departures line TA & ROUNDED $=5.5$ minutes \\
\hline Interval between bus departures line TB & ROUNDED $=3.0$ minutes \\
\hline Interval between bus departures line TC & ROUNDED $=7.5$ minutes \\
\hline $\begin{array}{l}\text { Time spend from bus line TA (considering comings } \\
\text { and goings) }\end{array}$ & $37.24 \mathrm{~min}$ \\
\hline $\begin{array}{l}\text { Time spend from bus line TB (considering comings } \\
\text { and goings) }\end{array}$ & $26.68 \mathrm{~min}$ \\
\hline $\begin{array}{l}\text { Time spend from bus line TC (considering comings } \\
\text { and goings) }\end{array}$ & $23.8 \mathrm{~min}$ \\
\hline Number of necessary buses for line A & ROUNDED $=7$ \\
\hline Number of necessary buses for line B & ROUNDED $=9$ \\
\hline Number of necessary buses for line $\mathrm{C}$ & ROUNDED $=4$ \\
\hline Total number of buses & 20 \\
\hline
\end{tabular}

Table 4 shows the timetable for the three bus lines based on the data obtained above. The program also gives the results in the form of graphics but due to the lot of lines under study the data on the beginning would be overlapping making it hard for readers to understand. 
Development of an Integrated Metrô-Bus Transportation System Using the Mathematica Software

Table 4. Timetable results for the first studied case based on data from table 1 and 3 for the 3 bus lines.

\begin{tabular}{|c|c|c|c|c|c|}
\hline \multicolumn{2}{|c|}{ Bus Line TA time table } & \multicolumn{2}{|c|}{ Bus Line TB time table } & \multicolumn{2}{|c|}{ Bus Line TC time table } \\
\hline Arrivals & Departures & Arrivals & Departures & Arrivals & Departures \\
\hline $0 \mathrm{~min}$ & 5 min & $0 \mathrm{~min}$ & $5 \mathrm{~min}$ & $0 \mathrm{~min}$ & $5 \mathrm{~min}$ \\
\hline $5.5 \mathrm{~min}$ & $10.5 \mathrm{~min}$ & $3 \mathrm{~min}$ & $8 \mathrm{~min}$ & $7.5 \mathrm{~min}$ & $12.5 \mathrm{~min}$ \\
\hline 11. $\min$ & 16. $\min$ & $6 \min$ & $11 \mathrm{~min}$ & 15. $\min$ & 20. $\min$ \\
\hline $16.5 \mathrm{~min}$ & $21.5 \mathrm{~min}$ & $9 \mathrm{~min}$ & $14 \mathrm{~min}$ & $22.5 \mathrm{~min}$ & $27.5 \mathrm{~min}$ \\
\hline 22. $\min$ & 27. $\min$ & $12 \min$ & $17 \mathrm{~min}$ & 30. min & 35. min \\
\hline $27.5 \mathrm{~min}$ & $32.5 \mathrm{~min}$ & $15 \mathrm{~min}$ & $20 \mathrm{~min}$ & $37.5 \mathrm{~min}$ & $42.5 \mathrm{~min}$ \\
\hline 33. min & 38. min & $18 \mathrm{~min}$ & $23 \mathrm{~min}$ & $45 \min$ & 50. min \\
\hline $38.5 \mathrm{~min}$ & $43.5 \mathrm{~min}$ & $21 \mathrm{~min}$ & $26 \min$ & $52.5 \mathrm{~min}$ & $57.5 \mathrm{~min}$ \\
\hline 44. $\min$ & 49. $\min$ & $24 \mathrm{~min}$ & $29 \mathrm{~min}$ & & \\
\hline $49.5 \mathrm{~min}$ & $54.5 \mathrm{~min}$ & $27 \mathrm{~min}$ & $32 \mathrm{~min}$ & & \\
\hline $55.0 \mathrm{~min}$ & $60 \min$ & $30 \mathrm{~min}$ & $35 \mathrm{~min}$ & & \\
\hline & & $33 \mathrm{~min}$ & $38 \mathrm{~min}$ & & \\
\hline & & $36 \mathrm{~min}$ & $41 \mathrm{~min}$ & & \\
\hline & & $39 \mathrm{~min}$ & $44 \mathrm{~min}$ & & \\
\hline & & $42 \mathrm{~min}$ & $47 \mathrm{~min}$ & & \\
\hline & & $45 \mathrm{~min}$ & $50 \mathrm{~min}$ & & \\
\hline & & $48 \mathrm{~min}$ & $53 \mathrm{~min}$ & & \\
\hline & & $51 \mathrm{~min}$ & $56 \mathrm{~min}$ & & \\
\hline & & $54 \mathrm{~min}$ & $59 \mathrm{~min}$ & & \\
\hline & & $57 \mathrm{~min}$ & $62 \mathrm{~min}$ & & \\
\hline
\end{tabular}

Source: Authors.

Table 5 shows the main results obtained using the table 2 data for case 2 .

Table 5. System results for the second set of data from table 2.

\begin{tabular}{lr}
\hline \multicolumn{1}{c}{ System characteristic } & Values \\
\hline Total distance MS-TA & $6.3 \mathrm{~km}$ \\
Total distance MS-TB & $4.1 \mathrm{~km}$ \\
Total distance MS-TC & $3.5 \mathrm{~km}$ \\
Average velocity on all routes & $0.5 \mathrm{~km} / \mathrm{min}$ \\
Number of metro wagons per hour arriving at station & 5 \\
Number of passengers per hour at the station & 5000 passengers/h \\
Number of passengers that takes bus line TA & 851 passengers/hour \\
Number of passengers that takes bus line TB & 1670 passengers/hour \\
Number of passengers that takes bus line TC & 630 passengers/hour \\
Number of circulating bus per hour for line TA & irculation buses/hour (not the \\
& number necessary per line) \\
Number of circulating bus per hour for line TB & number necessary per line) \\
Number of circulating bus per hour for line TC & 7 circulation buses/hora (not the \\
& number necessary per line) \\
Interval between bus departures line TA & 7 minutes \\
Interval between bus departures line TB & 4 minutes \\
Interval between bus departures line TC & 9 minutes \\
Time spend from bus line TA (considering comings and goings & 32.2 min \\
Time spend from bus line TB (considering comings and goings & 23.4 min \\
Time spend from bus line TC (considering comings and goings & 21 min \\
Number of necessary buses for line A & 5 \\
Number of necessary buses for line B & 6
\end{tabular}


Number of necessary buses for line C

3

Total number of buses

14

Source: Authors.

Table 6 shows the timetable obtained for the three bus lines based on the set of data from case 2.

Table 6. Timetable results for the second studied case based on data from table 2 and 5 for the 3 bus lines.

\begin{tabular}{|c|c|c|c|c|c|}
\hline \multicolumn{2}{|c|}{ Bus Line TA time table } & \multicolumn{2}{|c|}{ Bus Line TB time table } & \multicolumn{2}{|c|}{ Bus Line TC time table } \\
\hline Arrivals & Departures & Arrivals & Departures & Arrivals & Departures \\
\hline $0 \mathrm{~min}$ & $5 \mathrm{~min}$ & $0 \mathrm{~min}$ & $5 \min$ & $0 \mathrm{~min}$ & $5 \min$ \\
\hline $7 \mathrm{~min}$ & $12 \min$ & $4 \mathrm{~min}$ & $9 \min$ & $9 \min$ & $14 \mathrm{~min}$ \\
\hline $14 \mathrm{~min}$ & $19 \mathrm{~min}$ & $8 \mathrm{~min}$ & $13 \mathrm{~min}$ & $18 \mathrm{~min}$ & $23 \mathrm{~min}$ \\
\hline $21 \mathrm{~min}$ & $26 \min$ & $12 \mathrm{~min}$ & $17 \mathrm{~min}$ & $27 \mathrm{~min}$ & $32 \mathrm{~min}$ \\
\hline $28 \mathrm{~min}$ & $33 \mathrm{~min}$ & $16 \mathrm{~min}$ & $21 \mathrm{~min}$ & $36 \mathrm{~min}$ & $41 \mathrm{~min}$ \\
\hline $35 \mathrm{~min}$ & $40 \mathrm{~min}$ & $20 \mathrm{~min}$ & $25 \mathrm{~min}$ & $45 \mathrm{~min}$ & $50 \mathrm{~min}$ \\
\hline $42 \mathrm{~min}$ & $47 \mathrm{~min}$ & $24 \min$ & $29 \mathrm{~min}$ & $54 \mathrm{~min}$ & $59 \mathrm{~min}$ \\
\hline $49 \mathrm{~min}$ & $54 \mathrm{~min}$ & $28 \mathrm{~min}$ & $33 \mathrm{~min}$ & & \\
\hline & & $32 \mathrm{~min}$ & $37 \mathrm{~min}$ & & \\
\hline & & $36 \min$ & $41 \mathrm{~min}$ & & \\
\hline & & $40 \mathrm{~min}$ & $45 \mathrm{~min}$ & & \\
\hline & & $44 \mathrm{~min}$ & $49 \mathrm{~min}$ & & \\
\hline & & $48 \mathrm{~min}$ & $53 \mathrm{~min}$ & & \\
\hline & & $52 \mathrm{~min}$ & $57 \mathrm{~min}$ & & \\
\hline & & $56 \mathrm{~min}$ & & & \\
\hline
\end{tabular}

Source: Authors.

It can be seen from table 4 and 6 that the timetable changes due to the number of the metro passengers as well as with the average buses velocities. diminishing the number of metro passengers and increasing the buses velocities as on the second example less buses are necessary for each line.

The program allows correlating any change in one of the parameters involved in the model with the results of the system and consequently determining the most important data where a better research is needed.

All the data listed from table 1 can be easily changed in the program to find the new number of necessary buses for each path (TA, TB and TC) as well as the news timetables for each line. Also new bus lines can be added to the program if desired. 
Development of an Integrated Metrô-Bus Transportation System Using the Mathematica Software

\section{CONCLUSIONS}

The article presented two examples of combined metro-bus system developed in the Mathematica platform and shows how to easily calculate de necessary number of buses lines for each pathway as well as the correspondent bus line timetables depending on the many parameters involved on the model system shown on the equations used.

The article also pointed out the most important parameters when you are establishing an integrated metro-bus system and showed how the number of passengers and the average bus velocity influenced on the results.

The results show that an integrated system using a symbolic language computer program, as MATHEMATICA, can contribute to urban logistics, reducing the waiting time and the time of travel of the systems. The study is an important tool that can help in the management and planning of transport systems, favoring the improvement of urban mobility, and can be applied in areas that have the same similarities, with greater or lesser demand for public transportation.

The authors would like to highlight the innovative and practical character of the use of symbolic programming that, although not shown in the article, because was not the main objective, allows for example, the inclusion of figures, maps showing the buses paths, etc, under study, which facilitates the use and understanding of the program, while running it, transforming it in a friendly use system if desired.

Lastly, we can highlight that the program can be modified to include other types of mode transport with subway connections, such as light transport on rails, ferries, by knowing the capacity of each of these transport modes in terms of passengers, demands, average speed, time per stop, if any, and other important parameters as shown on this article.

\section{ACKNOWLEDGMENTS}

We thank the reviewers for the considerations for improving the article. To the Civil Engineering Program of PUC-RJ and to the Civil Engineering Program (PEC/COPPE/UFRJ), for the support to the development of the research. 


\section{REFERENCES}

AAKASH, N.; KARTHICK, V. Metro Bus Live Tracking Using Smartphone. International Journal of Recent Technology and Engineering (IJRTE). Volume-7, Issue-6S4, 2019.

ALMASI, M.; SADOLLAH, A.; KANG, S.; KARIM, M. Optimization of an improved intermodal transit model equipped with feeder bus and railway systems using metaheuristics approaches. Sustainability, 8(6), 537, 2016.

BABALIK-SUTCLIFFE, E.; CENGIZ, E. C. Bus rapid transit system in Istanbul: a success story or flawed planning decision?. Transport Reviews, 35(6), 792-813, 2015.

BILIŞIK, Ö. N.; ERDOĞAN, M.; KAYA, İ.; BARAÇLI, H. A hybrid fuzzy methodology to evaluate customer satisfaction in a public transportation system for Istanbul. Total Quality Management \& Business Excellence, 24(9-10), 1141-1159, 2013.

CARVALHO, C. H. R. (2016). Desafios da mobilidade urbana no Brasil (No. 2198). Texto para Discussão, Instituto de Pesquisa Econômica Aplicada (IPEA).

CORREIA, G. Apontamentos da Disciplina de Planejamento de Transportes. Departamento de Engenharia Civil e Ambiente. 2012. Faculdade de Ciências e Tecnologia da Universidade de Coimbra, Coimbra.

CHAKRABARTI, S.; GIULIANO, G. Does service reliability determine transit patronage? Insights from the Los Angeles Metro bus system. Transport policy, 42, 12-20, 2015.

CHAKRABARTI, S. The demand for reliable transit service: New evidence using stop level data from the Los Angeles Metro bus system. Journal of Transport Geography, 48, 154-164, 2015.

CHENG, Y. H.; TSENG, W. C. Exploring the effects of perceived values, free bus transfer, and penalties on intermodal metro-bus transfer users' intention. Transport Policy, 47, 127-138, 2016.

FERRAZ, A.C.P.; TORRES, I.G.E. Transporte Público Urbano. São Carlos: RiMa, 2001.

GEURS, K. T.; LA PAIX, L.; VAN WEPEREN, S. A multi-modal network approach to model public transport accessibility impacts of bicycle-train integration policies. European transport research review, 8(4), 25, 2016.

HIDALG0, D. Citywide transit integration in a large city: The Interligado system of Sao Paulo, Brazil. Transportation Research Record, 2114(1), 19-27, 2009.

IPEA. Instituto de Pesquisa Econômica Aplicada. Dinâmica populacional e sistema de mobilidade nas metrópoles brasileiras. Brasília: IPEA, 2011. (Comunicado, n. 102). Disponível em http://www.ipea.gov.br/portal/images/stories/PDFs/comunicado/110728_comunicadoipeal02.pdf.

JIN, J.G.; TANG, L.C.; SUN, L.; LEE, D.H. Enhancing metro network resilience via localized integration with bus services. Transportation Research Part E: Logistics and Transportation Review, 63, 17-30, 2014.

KEPAPTSOGLOU, K.; KARLAFTIS, M. G. The bus bridging problem in metro operations: conceptual framework, models and algorithms. Public Transport, 1(4), 275-297, 2009.

KÖNIGSBERG, Z. R. A generalized eigenmode algorithm for reducible regular matrices over the max-plus algebra with applications to the Metro-bus public transport system in Mexico city. Nonlinear Analysis: Hybrid Systems, 2(4), 1205-1216, 2008.

KUMAR, P.; KULKARNI, S. Y., \& PARIDA, M. Security perceptions of Delhi commuters at Metro-bus interchange in multi modal perspective. Journal of transportation security, 4(4), 295-307, 2011.

LI, F., YU, Y., LIN, H., \& MIN, W. Public bus arrival time prediction based on traffic information management system. In: PROCEEDINGS OF 2011 IEEE INTERNATIONAL CONFERENCE ON SERVICE OPERATIONS, LOGISTICS AND INF0RMATICS, pp. 336-341, 2011. 
Development of an Integrated Metrô-Bus Transportation System Using the Mathematica Software

MATA, F., JARAMILLO, A., \& CLARAMUNT, C. A mobile navigation and orientation system for blind users in a metrobus environment. In: INTERNATIONAL SYMPOSIUM ON WEB AND WIRELESS GEOGRAPHICAL INFORMATION SYSTEMS, pp. 94-108, Berlin, 2011.

OGUCHI, T.; MITSUYASU, A.; OSHIMA, D.; IMAGAWA, T. An evaluation study on advanced public transport priority system using traffic simulation. Int. J. Urban Sci., 2, 43-53, 2017.

PEKEL, E., \& KARA, S. S. Simulation-based fleet scheduling in the Metrobus. International Journal of Simulation and Process Modelling, 11(3-4), 326-336, 2016.

PENA, R. F. A. (2017). Mobilidade urbana no Brasil. Brasil Escola. Disponível em: https://brasilescola.uol.com.br/geografia/mobilidade-urbana-no-brasil.htm Acesso em 17 de setembro de 2019.

SERIANI, S., \& FERNÁNDEZ, R. Planning guidelines for metro-bus interchanges by means of a pedestrian microsimulation model. Transportation Planning and Technology, 38(5), 569-583, 2015.

SONG, L., CHEN, F., XIAN, K., \& SUN, M. Research on a scientific approach for bus and metro networks integration. Procedia-Social and Behavioral Sciences, 43, 740-747, 2012.

THILAKARATNE, R.S.; WIRASINGHE, S.C. Implementation of Bus Rapid Transit (BRT) on an optimal segment of a long regular bus route. Int. J. Urban Sci. 20, 15-29, 2016.

Wolfram, S. The MATHEMATICA® software, version 3. Wolfram Research (Champaign, \& Illinois), 1996.

VUCHIC, V. Urban Transit: Systems and Technology. John Wiley and Sons, 2007. 624 p.

VUCHIC, V. Urban Transit: Operations, Planning, and Economics. John Wiley and Sons, 2005. 672 p.

YANNIS, G., KOPSACHEILI, A., \& KLIMIS, P. Estimating the adequacy of a metro network. Journal of Urban Planning and Development, 138(4), 286-292, 2012.

YIN, H., WU, J., SUN, H., QU, Y., YANG, X., \& WANG, B. Optimal Bus-Bridging Service under a Metro Station Disruption. Journal of Advanced Transportation, 2018.

XIONG, J.; GUAN, W.; SONG, L.; HUANG, A.; SHA0, C. Optimal routing design of a community shuttle for metro stations. Journal of Transportation Engineering, 139(12), 1211-1223, 2013. 